\title{
SYNTHESIS OF 3-OXO-3-PHENYL-2,2,5-TRIMETHYL-1,3-OXAPHOSPHORINANES AND THEIR TETRAFLUOROBORATE SALTS
}

\author{
SUSANA LÓPEZ CORTINA*, PERLA ELIZONDO MARTÍNEZ, NANCY PÉREZ RODRIGUEZ, EUGENIO \\ HERNÁNDEZ FERNÁNDEZ \\ Facultad de Ciencias Químicas, Universidad Autónoma de Nuevo León, Av. Universidad s/n, Cd. Universitaria, \\ 66451, San Nicolás de los Garza, Nuevo León, México. \\ *e-mail: susalas75@gmail.com
}

MARIO FERNÁNDEZZERTUCHE

Centro de Investigaciones Químicas, Universidad Autónoma del Edo. de Morelos, Av. Universidad 1001, Col. Chamilpa, 62209, Cuernavaca, Morelos, México.

\begin{abstract}
The synthesis and characterization of cis- and trans-3-oxo-3-phenyl-2,2,5-trimethyl-1,3-oxaphosphorinanes (7a and 7b) and their corresponding tetrafluoroborate salts ( $3 \mathrm{a}$ and $3 \mathrm{~b}$ ), heterocyclic organophosphorus compounds not previously reported in the literature, was accomplished. They were fully characterized by ${ }^{1} \mathrm{H},{ }^{13} \mathrm{C}$ and ${ }^{31} \mathrm{P}$ NMR. It was established the relative configuration of these compounds on the basis of an X-ray diffraction study of oxide $7 \mathrm{a}$.
\end{abstract}

\section{Introduction}

Phosphorus-containing compounds and their chemistry have gained considerable attention as a result of their biological and chemical profiles [1,2]. The most frequently encountered reactions in phosphorus chemistry are nucleophilic substitutions; such reactions at tetravalent phosphorus centers are involved in a number of cellular energetic and biosynthesis processes [3]. In this context, quaternary phosphonium salts undergo nucleophilic displacement reactions induced by aqueous hydroxide ion to yield phosphine oxides [4] and with few exceptions, these reactions have shown inversion of configuration at phosphorus as the stereochemical course [5]. In cyclic phosphonium salts, however, the stereochemical behavior is much more complex, in six-membered rings the most studied leaving groups have been the benzyl and the methoxy groups attached to the phosphorus atom. When the benzyl group is used as the leaving group, the reaction with base is non-stereospecific yielding phosphine oxides as mixtures of different proportions [6]. However, when the more electronegative methoxy group is used as the leaving group, pure samples of $c i s$ and trans 4-methyl (1a and $\mathbf{1 b}$ ) or 4-t-butyl (3a and $\mathbf{3 b}$ ) afford the corresponding phosphine oxides $\mathbf{2}$ or $\mathbf{4}$ (Scheme 1) with complete inversion of configuration at phosphorus [7].

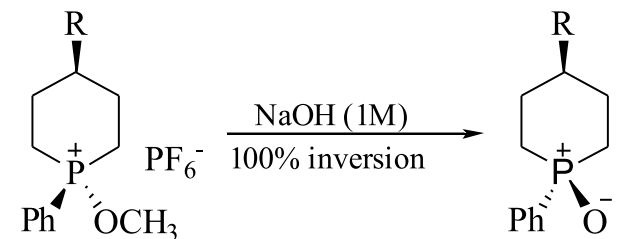

1a $\mathbf{R}=\mathrm{CH}_{3}$ 3a $\mathbf{R}=\mathrm{t}-\mathrm{Bu}$

$$
\mathbf{2 b} \mathbf{R}=\mathrm{CH}_{3}
$$

$4 \mathbf{b} \mathbf{R}=\mathrm{t}-\mathrm{Bu}$

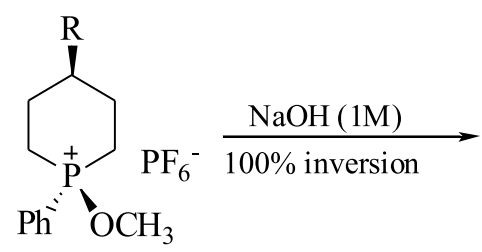

$\mathbf{1 b} \mathbf{R}=\mathrm{CH}_{3}$

$\mathbf{3 b} \mathbf{R}=\mathrm{t}-\mathrm{Bu}$

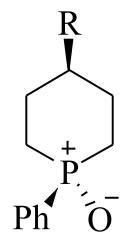

2a $\mathbf{R}=\mathrm{CH}_{3}$ 4a $\mathbf{R}=\mathrm{t}-\mathrm{Bu}$

Scheme 1. Stereochemical behavior of phosphorinanium salts.

We have reported our results about the hydroxide-induced displacement of the methoxy groups on samples of pure cis and trans isomers of 3-methoxy-2,2,6-trimethyl-3-phenyl-1,3-oxaphosphorinanium tetrafluoroborate salts $5 \mathrm{a}$ and $5 \mathrm{~b}$ (Scheme 2), systems designed to study the effect of a second heteroatom in the ring system on the stereochemistry of the reaction. In our study, the presence of the oxygen atom induces a different stereochemical outcome since $5 \mathrm{a}$ and $5 \mathrm{~b}$ reacted with base to yield the phosphine oxides $6 \mathrm{a}$ and $6 \mathrm{~b}$ with complete retention of configuration at phosphorus [8]. This study contrasts with the results observed in five-membered rings where the presence of the oxygen has no effect on the stereochemistry of the reaction [9]. 

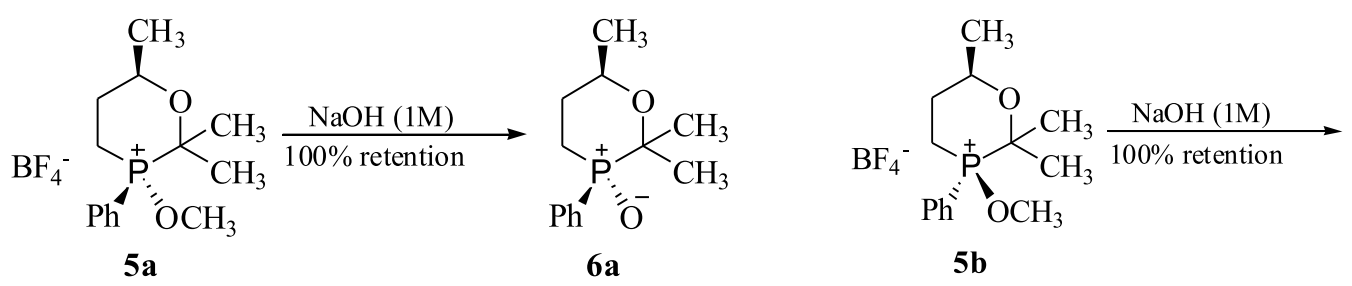<smiles>[2H][PH]1([O-])CCC(C)OC1(C)C</smiles>

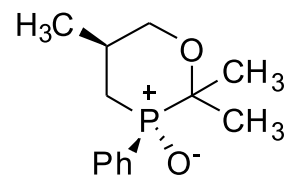

$7 a$<smiles>CC1COC(C)(C)P(=O)(Oc2ccccc2)C1</smiles>

$7 b$<smiles>C[C@H]1COC(C)(C)P(O)(=[Pb])C1</smiles>

$8 a$<smiles>C[C@H]1COC(C)(C)[P@](C)(c2ccccc2)C1</smiles>

$8 b$ 
2.1.2 Synthesis and separation of cis- and trans- 3-oxo-3-phenyl-2,2,5-trimethyl-1,3oxaphosphorinane, 7. 3-hydroxy-2-methylpropylphenylphosphine, 11 (1g, $5.49 \mathrm{mmol})$, dissolved in $30 \mathrm{~mL}$ of benzene, was mixed with $8.1 \mathrm{~mL}(0.11 \mathrm{~mol})$ of anhydrous acetone, then $0.05 \mathrm{~g}(0.29 \mathrm{mmol})$ of dried $p$-toluensulfonic acidwas added [11]. The reaction mixture was refluxed at $100^{\circ} \mathrm{C}$ for $42 \mathrm{~h}$ using a Dean-Stark trap. At this point an additional portion $(5.45 \mathrm{~mL}, 0.074 \mathrm{~mol})$ of acetone was added and the reaction mixture was kept at reflux for an additional period of $50 \mathrm{~h}$. After removal of the solvent, oxidation of the crude product was carried out by dissolving the material in $20 \mathrm{~mL}$ of benzene and adding at $0^{\circ} \mathrm{C}, 1.1 \mathrm{~mL}(5.54 \mathrm{mmol})$ of 5.0M tert-butylhydroperoxide in decane [12]. After the addition was completed, the reaction was allowed to reach room temperature and was stirred overnight at this temperature. The solvent was evaporated in vacuo and the crude product purified by flash column (silica-gel/ dichloromethane-isopropanol 90-10) to give $0.14 \mathrm{~g}$ (13\% yield) of the diasteromeric oxides of 7 . The mixture was separated by chromatographic column (silica gel 230-400/ dichloromethaneisopropanol 95-5), obtaining isomerically pure samples of cis- and trans- oxides. 3-oxo-r-3-phenyl2,2,c-5-trimethyl-1,3-oxaphosphorinane, 7a. ${ }^{31} \mathrm{P} \mathrm{NMR}\left(\mathrm{CDCl}_{3}\right) \quad+30.420 ;{ }^{1} \mathrm{H} \mathrm{NMR}\left(\mathrm{CDCl}_{3}\right) \quad 1.03$ $(\mathrm{dd}, J=6.6, \mathrm{~J}=2.2,3 \mathrm{H}), 1.26(\mathrm{~d}, J=13.6,3 \mathrm{H}), 1.40(\mathrm{~d}, J=12 \mathrm{~Hz}, 3 \mathrm{H}), 2.12(\mathrm{~m}, 2 \mathrm{H}), 2.73(\mathrm{~m}, 1 \mathrm{H})$, $3.51(\mathrm{dd}, J=12.2, \mathrm{~J}=11.8,1 \mathrm{H}), 3.81(\mathrm{~m}, J=12.2, J=4.5, J=2.05, J=2.05,1 \mathrm{H}), 7.49(\mathrm{~m}, 2 \mathrm{H}), 7.55$ $(\mathrm{m}, 1 \mathrm{H}), 7.77(\mathrm{~m}, 2 \mathrm{H}) ;{ }^{13} \mathrm{CNMR}\left(\mathrm{CDCl}_{3}\right)$ 19.16 (d, $\left.J=13.77\right), 21.36(\mathrm{~d}, J=12.26), 23.13(\mathrm{~s}), 28.07$ (d, $J=4.52), 29.49$ (d, $J=61.12), 68.86$ (d, $J=4.52), 73.93$ (d, $J=76.30), 128.79$ (d, $J=10.66$ ), 130.18 (s), 131.47 (d, $J=9.15$ ), 132.35 (s). Anal. Calcd for $\mathrm{C}_{13} \mathrm{H}_{19} \mathrm{O}_{2} \mathrm{P}: \mathrm{C}, 65.53 ; \mathrm{H}, 8.037$. Found: C, 65.33; H, 7.81. 3-oxo-r-3-phenyl-2,2,t-5-trimethyl-1,3-oxaphosphorinane, 7b. ${ }^{31} \mathrm{P}$ NMR $\left(\mathrm{CDCl}_{3}\right)$ $+29.17 ;{ }^{1} \mathrm{H} \mathrm{NMR}\left(\mathrm{CDCl}_{3}\right) 0.945(\mathrm{dd}, J=6.4, J=2.8,3 \mathrm{H}), 1.27(\mathrm{~d}, J=13.2,3 \mathrm{H}), 1.66(\mathrm{~d}, J=11.2,3 \mathrm{H})$, $2.0(\mathrm{~m}, 2 \mathrm{H}), 2.40(\mathrm{~m}, 1 \mathrm{H}), 3.51(\mathrm{dd}, J=11.9,1 \mathrm{H}), 3.76(\mathrm{~m}, J=12.47, J=4.28, J=2.1, J=2.1,1 \mathrm{H})$, $7.51(\mathrm{~m}, 3 \mathrm{H}), 8.10(\mathrm{~m}, 2 \mathrm{H}) ;{ }^{13} \mathrm{C} \mathrm{NMR}\left(\mathrm{CDCl}_{3}\right) 18.81(\mathrm{~d}, J=13.67), 19.86(\mathrm{~d}, J=7.64), 24.12(\mathrm{~d}, J=$ 3.015), 32.0 (d, $J=4.62), 33.06$ (d, $J=56.39), 67.89$ (d, $J=5.63), 73.72$ (d, $J=77.81), 128.47$ (d, $J=$ 10.66), $131.04(\mathrm{~s}), 131.87$ (s), 132.21 (s). Anal. Calcd for $\mathrm{C}_{13} \mathrm{H}_{19} \mathrm{O}_{2} \mathrm{P}: \mathrm{C}, 65.53 ; \mathrm{H}$, 8.037. Found: $\mathrm{C}$, $65.6 ; \mathrm{H}, 8.15$.

2.1.3 Synthesis of cis- and trans- 3-methoxy-3-phenyl-2,2,5-trimethyl-1,3-oxaphosphorinanium tetrafluoroborate, 8. For the preparation of the cis isomer 8a, $0.039 \mathrm{~g}(0.164 \mathrm{mmol})$ of the cis phosphine oxide $7 \mathbf{a}$ was dissolved in $20 \mathrm{~mL}$ of dry methylene chloride. This solution was added to a suspension of $0.032 \mathrm{~g}(0.216 \mathrm{mmol})$ of trimethyloxonium tetrafluoroborate in dry methylene chloride and the resulting mixture was stirred at room temperature for $6 \mathrm{~h}$. The solution was evaporated to dryness in vacuo to give $0.044 \mathrm{~g}$ (79\% yield) of the cis isomer, 8a, ${ }^{31} \mathrm{PNMR}\left(\mathrm{CDCl}_{3}\right) \delta+72.43 ;{ }^{1} \mathrm{H} \mathrm{NMR}$ $\left(\mathrm{CDCl}_{3}\right) 1.09(\mathrm{dd}, J=6.4, J=2.8,3 \mathrm{H}), 1.31(\mathrm{~d}, J=16.4,3 \mathrm{H}), 1.48(\mathrm{~d}, J=12.8,3 \mathrm{H}), 2.55(\mathrm{~m}, 3 \mathrm{H})$, $3.52(\mathrm{dd}, J=12.0, J=11.9,1 \mathrm{H}), 4.03(\mathrm{~d}, J=11.4,3 \mathrm{H}), 7.73(\mathrm{~m}, 5 \mathrm{H})$. Trans isomer $\mathbf{8 b}$, was prepared in a similar way from $7 \mathbf{b}$ (trans oxide), evaporation of the solvent afforded $0.038 \mathrm{~g}$ ( $68 \%$ yield) of trans isomer 8b, ${ }^{31} \mathrm{P} \mathrm{NMR}\left(\mathrm{CDCl}_{3}\right) \quad+68.30 ;{ }^{1} \mathrm{H} \mathrm{NMR}\left(\mathrm{CDCl}_{3}\right) 1.04(\mathrm{dd}, J=5.8, J=3.5,3 \mathrm{H}), 1.39(\mathrm{~d}, J=$ $16.6,3 \mathrm{H}), 1.8(\mathrm{~d}, J=14.0,3 \mathrm{H}), 3.05(\mathrm{~m}, 3 \mathrm{H}), 3.78(\mathrm{~m}, 2 \mathrm{H}), 4.1(\mathrm{~d}, J=11.4,3 \mathrm{H}), 7.82(\mathrm{~m}, 5 \mathrm{H})$. 
Empirical formula

Formula weight

Temperature

Wavelength

Crystal system

Space group

Unit cell dimensions

Volume

Z

Density (calculated)

Absorption coefficient

$\mathrm{F}(000)$

Crystal size

Theta range for data collection

Index ranges

Reflections collected

Independent reflections

Completeness to theta $=28.25^{\circ}$

Refinement method

Data / restraints / parameters

Goodness-of-fit on $\mathrm{F}^{2}$

Final $R$ indices [I $>2 \operatorname{sigma}(\mathrm{I})]$

$\mathrm{R}$ indices (all data)

Largest diff. peak and hole 0.504 and $-0.328 \mathrm{e} . \AA^{-3}$
$\mathrm{C}_{13} \mathrm{H}_{19} \mathrm{O}_{2} \mathrm{P}$

238.25

273(2) K

$0.71073 \AA$

Monoclinic

$\mathrm{P} 2(1) / \mathrm{n}$

$\mathrm{a}=9.6486(11) \AA \quad \alpha=90^{\circ}$

$\mathrm{b}=14.6240(16) \AA \quad \beta=92.126(3)^{\circ}$

$\mathrm{c}=18.430(2) \AA \quad \gamma=90^{\circ}$

\section{$2598.7(5) \AA^{3}$}

8

\section{$1.218 \mathrm{Mg} / \mathrm{m}^{3}$}

$0.196 \mathrm{~mm}^{-1}$

1024

$0.21 \times 0.37 \times 0.39 \mathrm{~mm}^{3}$

1.78 to $28.25^{\circ}$

$-12<=\mathrm{h}<=12,-14<=\mathrm{k}<=18,-12<=1<=23$

10366

$5734[\mathrm{R}($ int $)=0.0147]$

$89.2 \%$

Full-matrix least-squares on $\mathrm{F}^{2}$

5734 / 0 / 295

1.022

$\mathrm{R} 1=0.0358, \mathrm{wR} 2=0.0973$

$\mathrm{R} 1=0.0391, \mathrm{wR} 2=0.0997$

\section{Results and discussion}

The synthesis of 1,3-oxaphosphorinane oxides 7 was accomplished following the proposed synthetic route (Scheme 3) in which 3-hydroxy-2-methylpropylphenylphosphine was prepared by the ring opening reaction of 3methyloxetane, 10, (prepared by an adaptation of the Searles' procedure [13]), by the lithium salt of phenylphosphine, 9 (synthesized by reduction of dichlorophenylphospine [14]). This procedure allowed us to obtain compound 11 (38\% yield). The following cyclization toward phosphorinanes oxides 7 , was carried out by an adaptation of Oheme's procedure [15], as we have previously published for the synthesis of 1,3oxaphosphorinane oxides using acetone as dimethyl group provider in the presence of $p$-toluensulphonic acid, followed by an oxidation using tert-butylhydroperoxide in benzene. The mixture of $\mathrm{cis}$ - and - diastereoisomers of the desired 1,3-oxaphosphorinanes was obtained (13\% yield). 


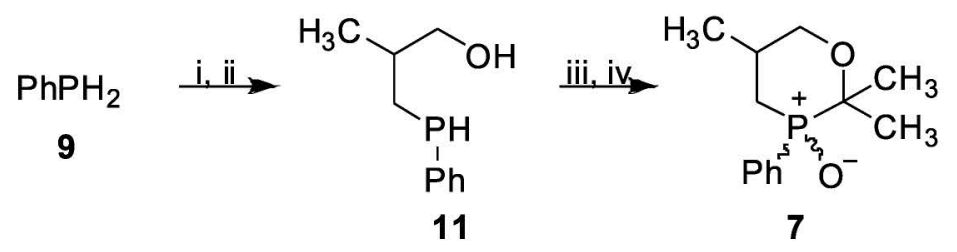

(i) $n$-BuLi, THF, $0^{\circ} \mathrm{C}$; (ii) 3-methyloxetane, $10,-78^{\circ} \mathrm{C}$;

(iii) $p$-TsOH, acetone, $\mathrm{C}_{6} \mathrm{H}_{6}$; (iv) $t-\mathrm{BuOOH}, \mathrm{C}_{6} \mathrm{H}_{6}$

The separation of the diastereomeric mixture of oxides 7 was accomplished by column chromatography (Scheme 4 ) leading to diastereoisomers $7 \mathrm{a}$ and $7 \mathrm{~b}$ in a very pure form.

Both compounds were fully characterized by NMR spectroscopy; however, the relative stereochemistry of these diastereoisomers $7 \mathrm{a}$ and $7 \mathrm{~b}$ were established by X-ray crystal structure determinations on isomer 7a. Figure 2 shows the X-ray crystal structure of this compound (cis isomer). Unfortunately, an appropriate crystal of $7 \mathrm{~b}$ could not be obtained for X-ray studies, however, its relative configuration (trans isomer) was established indirectly by the crystal structure of isomer $7 \mathrm{a}$.

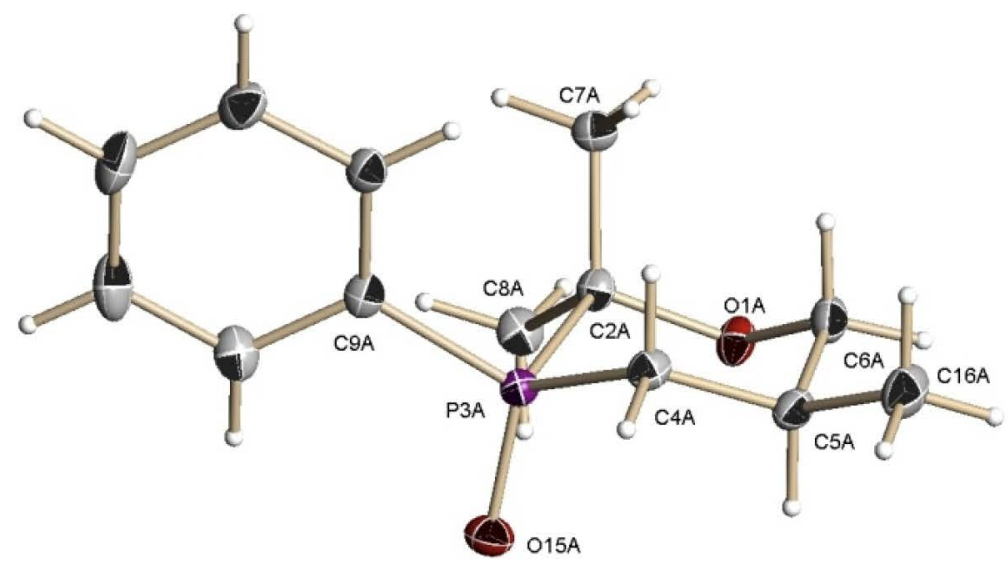


In the X-ray crystal structure of 7a (Figure 2) it can be observed the methyl group at $\mathrm{C}(5)$ and the phenyl substituent at phosphorus both oriented in equatorial position, establishing a cis relationship between them. It is then assumed that in isomer $7 \mathrm{~b}$, these groups must have a trans relationship. The fact that the six-membered ring adopts a flattened chair conformation at the phosphorus end, is suggested by the analysis of this region based on the torsional angles that involves the central fragment $\mathrm{P}(3)-\mathrm{C}(2)$, which shows angles of approximately $20^{\circ}$ degrees far from the ideal gauche conformation angle $\left(60^{\circ}\right)$ or anti conformation angle $\left(180^{\circ}\right)$.

In addition, the $\mathrm{O}(1)-\mathrm{C}(6)-\mathrm{C}(5)-\mathrm{C}(4)$ torsion angle at nearly $60^{\circ}\left(63.64^{\circ}\right)$ and the $\mathrm{C}(16)-\mathrm{C}(5)-\mathrm{C}(6)-\mathrm{O}(1)$ torsion angle at nearly $180^{\circ}$ show a normal chair-like conformation at $\mathrm{C}(5)$ and $\mathrm{C}(6)$. Incidentally, this latter angle $\left(174.26^{\circ}\right)$ also proves that the methyl group at $\mathrm{C}(5)$ occupies an equatorial position in $7 \mathrm{a}$.

It has been known that an equatorial phenyl group assumes a conformation in which it is parallel to the symmetry plane of the chair-shaped cyclohexane ring [16]. This could also applies for some 1-phenylphosphorinane derivatives [17]. In compound $7 \mathrm{a}$, torsional angles having $\mathrm{P}(3)-\mathrm{C}(9)$ as central fragment show values close to the expected conformation with the phenyl group parallel to the phosphorinane ring. Although transferring this behavior for the isomers in solution is not possible, one might expect that equatorial phenyl rings in $7 \mathrm{a}$ are almost free to rotate, presumably, the presence of the methyl groups at $\mathrm{C}(2)$ and the ring oxygen both placed near to the phenyl group, should be noticed in order to propose a conformational behavior in solution, however, this cannot be determined based only on the data reported here.

The ${ }^{1} \mathrm{H}$ NMR spectra of these compounds support a configurational assignment in which the methyl group at $\mathrm{C}(5)$ occupies an equatorial position in both isomers since a four bond coupling constants for the $\mathrm{CH}_{3}$ protons and phosphorus atom are observed, with values of $2.2 \mathrm{~Hz}$ for $7 \mathrm{a}$ and of $2.8 \mathrm{~Hz}$ for $7 \mathrm{~b}$. Additionaly, the coupling constants involving $\mathrm{H}_{\text {6axial }}$ in both isomers support the equatorial position of methyl group at $\mathrm{C}(5)$, in cis isomer, 7a, it could be clearly observed a geminal coupling with $\mathrm{H}_{6 e q u a t o r i a l}$ of $12.2 \mathrm{~Hz}$ and an axial-axial coupling with $\mathrm{H}_{5 \text { axial }}$ of $11.8 \mathrm{~Hz}$, values closed to the reported data of ciclohexanes. Special attention was given to $\mathrm{H}_{\text {6equatorial }}$ signal at $3.81 \mathrm{ppm}$, which presents a clear multiplicity of dddd, the first doublet of $12.2 \mathrm{~Hz}$ was assigned for the $\mathrm{H}_{6 \text { cequatorial }}$ $\mathrm{H}_{\text {6axial }}$ coupling also observed in H6axial signal, the second doublet of $4.5 \mathrm{~Hz}$ corresponds to the $\mathrm{H}_{\text {6equatorial }}-\mathrm{H}_{\text {5xxial }}$ coupling; it was also possible to observe a $W$ type four bond coupling of $2.1 \mathrm{~Hz}$ for $\mathrm{H}_{\text {6equatoral }}-\mathrm{H}_{\text {4equatorial }}$ and finally another four bond coupling of $2.1 \mathrm{~Hz}$ for $\mathrm{H}_{\text {6equatorial-p. }}$. Similar analysis of the protons on $\mathrm{C}(6)$ could be made for trans isomer $7 b$.

The relationship between the $\mathrm{C}(2)$ methyl groups and the $\mathrm{P}=\mathrm{O}$ group, provides additional support to our stereochemical assignment. The coupling constant $\left({ }^{3} J\right)$ between these methyl groups and the phosphorus atom on the $\mathrm{P}=\mathrm{O}$ function should have a lower magnitude when they have a cis disposition than when they have a trans disposition. In addition, the chemical shift of the methyl groups cis to the $\mathrm{P}=\mathrm{O}$ functionality should be downfield than the chemical shift of the methyl groups trans to the $\mathrm{P}=\mathrm{O}$ group [18].

Once the configurations of the phosphine oxides $7 \mathrm{a}$ and $7 \mathrm{~b}$ were established, compounds $8 \mathrm{a}$ and $8 \mathrm{~b}$ were obtained by direct methylation of $7 \mathrm{a}$ and $7 \mathrm{~b}$ with trimethyloxonium tetrafluoroborate. The configuration of $8 \mathrm{a}$ and $8 \mathrm{~b}$ was assigned based on the established configuration of their parents $7 \mathrm{a}$ and $7 \mathrm{~b}$ and the known fact that methylation of phosphine oxides with trimethyloxonium tetrafluoroborate preceeds with retention of configuration at phosphorus (Scheme 5) [19]. Some key NMR signals were used for the structural determination of these compounds; for example, the signals for the methoxy groups on both isomers appear as doublets centered around $4.0 \mathrm{ppm}$ as a result of the coupling of these protons with the adjacent phosphorus atom. Likewise, the ${ }^{3} \mathrm{~J}_{\mathrm{P} \text {. }}$ осн3) coupling constants of $11.4 \mathrm{~Hz}$ for both isomers are in agreement with the values previously reported by Marsi ior phosphorus cyclic compounds [7]. Finally, the ${ }^{31} \mathrm{P}$ NMR signals for each isomer appear at $+72.43 \mathrm{ppm}$ for $8 \mathrm{a}$ and $+68.3 \mathrm{ppm}$ for $8 \mathrm{~b}$. 
<smiles>C[C@@H]1COC(C)(C)[P]([O+])([O-])C1</smiles>

$7 a$<smiles>C[C@H]1COC(C)(C)[P@]([O-])(=[Po])C1</smiles>

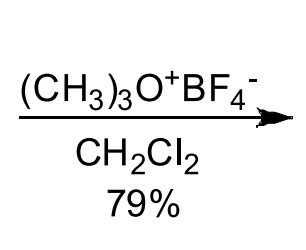

$\overbrace{\mathbf{8 a}}{ }_{\mathrm{Ph}}^{\mathrm{O}} \mathrm{OCH}_{\mathrm{CH}_{3}}^{\mathrm{CH}_{3}} \mathrm{BF}_{4}$

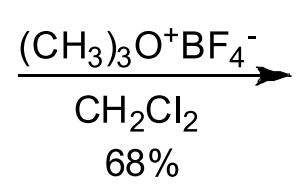<smiles>CO[P+]1(c2ccccc2)C[C@@H](C)COC1(C)C</smiles>

\section{Conclusions}

In this work, we have accomplished the synthesis of cis- and trans- 3-oxo-3-phenyl-2,2,5-trimethyl-1,3oxaphosphorinanes ( $7 \mathrm{a}$ and $7 \mathrm{~b}$ ) and their corresponding tetrafluoroborate salts (8a and $8 \mathrm{~b}$ ), heterocyclic organophosphorus compounds not previously reported in the literature. They were fully characterized by ${ }^{1} \mathrm{H},{ }^{13} \mathrm{C}$ and ${ }^{31} \mathrm{P}$ NMR. A very important part in the characterization of $7 \mathrm{a}$ and $7 \mathrm{~b}$ and indirectly of $8 \mathrm{a}$ and $8 \mathrm{a}$ was the establishment of the relative configuration of these compounds on the basis of an X-ray diffraction study of oxide $7 \mathrm{a}$. Finally, tetrafluoroborate salts $8 \mathrm{a}$ and $8 \mathrm{~b}$ reported here, could be considered as new target molecules for stereochemical behavior studies of base-induced cleavage, in order to determine the effect of the position of the methyl group on $\mathrm{C}(5)$ instead of on $\mathrm{C}(6)$ which was previously reported with complete retention of configuration at phosphorus [8].

\section{Acknowledgments}

The authors like to thank CONACyT of México (44704Q) for the financial support of this work. We are also indebted to Dr. Jorge Guerrero and Dr. Miguel Angel Muñoz (CIQ-UAEM, Mexico) for their valuable technical support with some NMR experiments and X-ray diffraction study carried out in some of these compounds.

\section{Appendix}

Includes the following data: atomic coordinates and equivalent isotropic displacement parameters; bond lengths and angles; anisotropic displacement parameters; hydrogen coordinates and isotropic displacement parameters; torsion angles. This section is available at http://www.fcq.uanl.mx

\section{References}

[1] K.C. Kumara Swamy, N. Satish Kumar, Acc. Chem. Res. 39 (2006) 324.

[2] (a) Long-Wu Ye, J. Zhou, Y. Tang, Chem. Soc. Rev. 37 (2008) 1140. (b) R. Martin, S.L. Buchwald, Acc. Chem. Res. 41 (2008) 1461. (c) B.M. Trost, M.R. Machacek, A. Aponick, Acc. Chem. Res. 39 (2006) 747. (d) T. Baumgartner, R. Reau, Chem. Rev. 106 (2006) 4681.

[3] (a) A.K.H. Hirsch, F.R. Fischer, F. Diederich, Angew. Chem. Int. Ed. Engl. 46 (2007) 338. (b) Z.Y. Zhang, Acc. Chem. Res. 36 (2003) 385. (c) Y. Takagi, M. Warashima, W.J. Stec, K. Yoshinari, K. Taira, Nucleic Acid Res. 29 (2001) 1815. (d) R.T. Raines, Chem. Rev. 98 (1998) 1045. (e) D.M. Perreault, E.V. Anslyn, Angew. Chem. Int. Ed. Engl. 36 (1997) 433.

[4] (a) P.A. Frey, Tetrahedron 38 (1982) 1541. (b) K. Bruzik, M.D. Tsai, J. Am. Chem. Soc. 106 (1984) 747. (c) W.E. McEwen, K.F. Kumli, A. Blade-Font, M.Zanger, C.A. Vander Werf, J. Am. Chem. Soc. 86(1964) 2378. (d) M. Zanger, C.A. VanderWerf, W.E. McEwen, J. Am. Chem. Soc. 81 (1959) 3806. (e) L. Horner, H. Winkler, A. Rapp, A. Mentrup, H. Hoffmann, P. Beck, Tetrahedron Lett. (1961) 161. 
[5] (a) O.I. Kolodiazhnyi, Tetrahedron:Asymm 9 (1998) 1279. (b) R. Z. Luckenbach, Naturforsch 31 b (1976) 1127. (c) G. Zon, K.E. De Bruin, K. Naumann, K. Mislow, J. Am. Chem. Soc. 91 (1969) 7023. (d) R. Luckenbach, Phosphorus 1 (1972) 223. (e) R. Luckenbach, Phosphorus 1 (1972) 229.

[6] K.L. Marsi, R.T. Clark, J. Am. Chem. Soc. 92 (1970) 3791.

[7] K.L. Marsi, J. Org. Chem. 40 (1975) 1779.

[8] S. López-Cortina, D.I. Basiulis, K.L. Marsi, M.A. Muñoz-Hernández, M. Ordoñez, M. Fernández-Zertuche, J. Org. Chem. $70(2005) 7473$.

[9] K.L. Marsi, M.E. Co-Sarno, J. Org. Chem. 42 (1977) 778.

[10] K. Issleib, H.R. Roloff, Chem. Ber. 98 (1965) 2091.

[11] Purification of Laboratory Chemicals; Perrin, D.D., Armarego, W.L.F., Pergamon Press, 3rd. ed, Great Britain (1989).

[12] D.B. Denney, J.W.Jr. Hanifin, Tetrahedron Lett. (1963) 2177.

[13] S.Jr. Searles, K.A. Pollart, F. Block, J. Am. Chem. Soc. 79 (1957) 952.

[14] W. Kuchen, H. Buchwald, Chem. Ber. 91 (1958) 2296.

[15] (a) H. Oehme, K. Issleib, E. Leissring, Tetrahedron 28 (1972) 2587. (b) K. Issleib, H. Oehme, M. Scheibe, Syn. Inorg. Metal-Org. Chem. 2 (1972) 223. (c) A. Zschunke, H. Meyer, E. Leissring, H. Oehme, K. Issleib, Phosphorus and Sulfur 5 (1978) 81.

[16] (a) D.J. Hodgson, U. Rychlewska, E.L. Eliel, M. Manoharan, D.E. Knox, E.M. Olefirowicz, J.Org.Chem. 50 (1985) 4838. (b) K.B. Wiberg, H. Castejon, W.F. Bailey, J. Ochterski, J.Org.Chem. 65 (2000) 1181. (c) Stereochemistry of Organic Compounds; Eliel, E.L., Wilen, S.H., John Wiley and Sons, Inc., New York, (1994).

[17] (a) N.L. Allinger, H. von Voithenberg, Tetrahedron 34 (1978) 627. (b) A.T. McPhail, J. J. Breen, L.D. Quin, J.Am.Chem.Soc. 93 (1971) 2574. (c) J.B. Rampal, J.B.; K.D. Berlin, J.P. Edasery, H. Satyamurthy, J.Org.Chem. 46 (1981) 1166.

[18] (a) A. Rudi, Y. Kashman, Tetrahedron Lett. (1978) 2209. (b) R. Bodalski, K.M. Pietrusiewicz, J. Koszuk, Tetrahedron 31 (1975) 1907. (c) G.A. Gray, S.E. Cremer, K.L. Marsi, J.Am.Chem.Soc. 98 (1976) 2109.

[19] (a) H. Meerwein, Org. Syn. 6 (1966) 120. (b) H.W. Heine, T.A. Newton, G.J. Blosick, K.C. Irving, C. Meyer, G.B. Corcoran III, J. Org. Chem. 38 (1973) 651. (c) von H. Hellman, J. Bader, H. Birkner, und O. Schumacher, Liebigs Ann. Chem. 48 (1962) 659. (d) H.O. House, F.A. jr. Richey, J. Org. Chem. 34 (1969) 1430. (e) K.L. Marsi, J.L. Jasperse, J.Org.Chem. 43 (1978) 760. (f) G. Zon, K.E. DeBruin, K. Naumann, K. Mislow, J.Am.Chem.Soc. 91 (1969) 7023. 